\section{Performance and Biodegradation in Soil of Novel Horticulture Containers Made from Bioplastics and Biocomposites}

\author{
Heidi A. Kratsch ${ }^{1,4}$, James A. Schrader ${ }^{2}$, Kenneth G. McCabe \\ Gowrishankar Srinivasan ${ }^{3}$, David Grewell ${ }^{3}$, and William R. Graves ${ }^{2}$
}

ADDITIONAL INDEX wORDs. greenhouse and nursery containers, biodegradable, biorenewable, sustainable, plastics, plant pots, waste reduction, biobased, green technology

SUMMARY. The container-crops industry relies heavily on single-use plant containers made from petroleum-based plastics, most of which contribute to the solid waste stream in landfills. Plant containers made from biorenewable materials have potential to be more sustainable, but most commercially available biocontainers are either not durable enough for common production cycles or do not effectively biodegrade in soil after use. In 2012 and 2013, we evaluated 28 novel biocontainers (injection-molded prototypes) for their performance during plant production and their biodegradation in soil at two sites with dissimilar soil and climate in Iowa and Nevada, and we compared their performance to that of commercially available biocontainers. Prototype containers made of blends or composites of polylactic acid (PLA) or polyhydroxyalkanoates (PHA) performed well during crop production, and many showed an effective rate of biodegradation in soil. Their rates of biodegradation in Nevada were either similar or lower than they were in Iowa, but the highest rated containers were acceptable for use in both locations. Adding biobased fibers of distiller's dried grains with solubles or corn stover to form composite materials improved biodegradation over that of the base polymers (PLA or PHA) and had little effect on container performance under greenhouse conditions. Many of the injection-molded prototypes performed as well as the petroleum control containers during crop production, yet biodegraded at similar or faster rates than commercially available fiber containers.

$\mathrm{T}$ he nursery and greenhouse industries are becoming increasingly sensitive to issues of environmental sustainability, a trend driven by consumer demand for products and practices that have low environmental impact (Behe et al., 2013; Hall et al., 2010). Single-use petroleum-based plant containers are widely used by the container-crops industry because of their excellent function, durability, and availability in a diversity of sizes and shapes. However, the use of petroleum-based

This research was supported in part by the USDA Specialty Crops Research Initiative (NIFA-SCRI 2011-51181-30735), Iowa State University, and the University of Nevada, Reno.

Mention of a trademark, proprietary product, or vendor does not constitute a guarantee or warranty of the product by the U.S. Dept. of Agriculture and does not imply its approval to the exclusion of other products or vendors that also may be suitable.

${ }^{1}$ University of Nevada Cooperative Extension, 4955 Energy Way, Reno, NV 89502

${ }^{2}$ Department of Horticulture, Iowa State University, Ames, IA 50011

${ }^{3}$ Department of Agricultural \& Biosystems Engineering, Iowa State University, Ames, IA 50011

${ }^{4}$ Corresponding author. E-mail: kratschh@unce.unr.edu. containers cannot be considered sustainable because they are made of fossil-based resources and are nonbiodegradable. In the United States, the container-crops industry produces over 4 billion container/plant units per year and uses over 1.6 billion pounds of petroleum plastic for containers (Schrader, 2013; Schrader et al., 2013). Because of contaminants and lack of infrastructure required for collection of used containers from customers, petroleum-based plant containers are rarely recycled or reused, and $\approx 98 \%$ of these containers end their life cycles as solid waste in landfills (Chappell and Knox, 2012; Yang et al., 2015).

Alternatives to petroleum-based plant containers are commercially available (Kuehny et al., 2011). Many of these are made of natural fibers, which are structurally inferior to conventional plastics and wick water through their sidewalls during crop production, resulting in higher production costs (Evans and Karcher, 2004; Koeser et al., 2013; McCabe et al., 2014). Plant containers made of bioplastic polymers and biocomposites are attractive additions to the list of biorenewable plant-container options. They have thermal and mechanical properties similar to those of petroleum plastics, infrastructure exists for injection-molding or blowmolding a variety of containers made from them, they are nontoxic, and many are biodegradable (Madbouly et al., 2014).

Bioplastics are polymer materials made from renewable biological sources or from products of biological processes. Some of these materials are already in common use in the food and beverage industry as packaging material, food containers, and waste bags (Madbouly et al., 2014). Common bioplastic materials include PLA and PHA, both of which are polymers produced through microbial metabolism of plant-based carbohydrates (Lu et al., 2014; Madbouly et al., 2014). Other types of bioplastics are made from proteins, such as soybean (Glycine max) or corn (Zea mays), and from biorenewable oils, such as castor oil (Ricinus communis) or tung oil (Vernicia fordii) (McCabe et al., 2014; Schrader et al., 2013).

Recent studies have evaluated the biodegradability of a variety of biorenewable materials, such as plant-based fibers and bioplastic compounds. Gómez and

\begin{tabular}{llll}
\hline $\begin{array}{l}\text { Units } \\
\text { To convert U.S. to SI, } \\
\text { multiply by }\end{array}$ & U.S. unit & SI unit & $\begin{array}{l}\text { To convert SI to U.S., } \\
\text { multiply by }\end{array}$ \\
\hline 29.5735 & fl oz & $\mathrm{mL}$ & 0.0338 \\
2.54 & inch(es) & $\mathrm{cm}$ & 0.3937 \\
25.4 & inch(es) & $\mathrm{mm}$ & 0.0394 \\
16.3871 & inch & $\mathrm{cm}^{3}$ & 0.0610 \\
0.4536 & $\mathrm{lb}$ & $\mathrm{kg}$ & 2.2046 \\
28.3495 & $\mathrm{oz}$ & $\mathrm{g}$ & 0.0353 \\
1 & $\mathrm{ppm}$ & $\mathrm{mg} \cdot \mathrm{kg}^{-1}$ & 1 \\
1 & $\mathrm{ppm}$ & $\mathrm{mg} \cdot \mathrm{L}^{-1}$ & 1 \\
0.9464 & $\mathrm{qt}$ & $\mathrm{L}$ & 1.0567 \\
$\left({ }^{\circ} \mathrm{F}-32\right) \div 1.8$ & ${ }^{\circ} \mathrm{F}$ & ${ }^{\circ} \mathrm{C}$ & $\left({ }^{\circ} \mathrm{C} \times 1.8\right)+32$
\end{tabular}


Michel (2013) demonstrated biodegradability of PHA-based bioplastics in a laboratory setting on a time-scale consistent with commercial composting processes. Madbouly et al. (2014) demonstrated biodegradation in soil of horticulture containers made from PHA biocomposites and showed that addition of $10 \mathrm{wt} \%$ distiller's dried grains with solubles (DDGS) substantially increased biodegradation compared with PHA without the filler. Schrader et al. (2013) showed that bioplastic plant containers made of a blended polymer of PLA and soy protein could provide a beneficial fertilizer effect for plants during greenhouse production and in the landscape when the container is removed, broken to smaller pieces, and installed near the plant roots.

Many types of bioplastic materials have been developed that can be used to manufacture plant containers with functional qualities similar to petroleum plastics but with reduced environmental impacts (Yang et al., 2015). The functional qualities of injection-molded plant containers formulated with biopolymers and biocomposites of soy protein, PHA, and PLA, with or without fillers, were rated similar to those of standard petroleum-based containers by Currey et al. (2014). Material strength and shelf life of containers formulated from PHA and PLA were highly rated, and plants produced in containers made of these materials were of equal or better health and size as those produced in petroleum-plastic containers (Grewell et al., 2014). Coating biofiber-based containers with bioplastic polymers of PLA, polyamide, or polyurethane was shown to improve their integrity, stability, and water-use efficiency during plant production without sacrificing their biodegradation in soil (McCabe et al., 2014).

The objectives of this work were to evaluate a variety of novel biocontainers made from bioplastic polymers and biocomposites to determine 1) their short-term and long-term biodegradability in two diverse soils and climates in Iowa and Nevada, 2) their resilience under conditions of plant production, $3)$ their effectiveness in facilitating healthy plant growth, and 4) to compare the effectiveness of the novel biocontainers to that of commercially available biocontainers, a top-performing bioplastic-coated fiber container, and a petroleum-based control. We hypothesized that many of the container types would biodegrade more completely and effectively in Iowa, where higher atmospheric humidity could maintain higher soil temperatures and reduce moisture evaporation from soil. Together with higher levels of soil organic matter than are present in Nevada soils, this could result in greater levels of biological activity in Iowa soils, facilitating a faster rate of material biodegradation. Results of this work are important to commercial operations interested in adopting the container technology. Widespread adoption will depend on many factors such as container function, durability, and effects on growth and health of plants. Knowledge of general climatic effects on biodegradation rate of containers will be especially important.

\section{Materials and methods}

In 2012 and 2013, we conducted experiments to evaluate the performance and biodegradation in soil of prototype horticulture containers made of bioplastic and biocomposite materials, along with control containers made of standard petroleumbased materials, as well as commercially available fiber containers. The study was performed in two phases with two sets of materials. Phase-1 evaluations, which began in 2012, were screening trials with 12 bioplastics and biocomposites and were designed to examine the potential of several biobased composite (filler) materials compounded with PLA and PHA (Table 1) and molded into containers with 4.5 -inch top diameters (volume $=$ $680 \mathrm{~cm}^{3}$ ) (Fig. 1). Phase-2 evaluations, which began in 2013, were trials of 17 bioplastic and biocomposite materials that were selected and improved based on results of phase- 1 trials to enhance durability during crop production by blending of polymers, to increase the rate of biodegradation after use by increasing percentage of filler, or to lower material costs by reducing container wall thickness and increasing percentage of filler. Phase- 2 materials were formed into containers of two sizes, 4.5 -inch top diameter (volume $=$ $680 \mathrm{~cm}^{3}$ ) (Fig. 2) and/or \#l trade gallon containers (volume $=3 \mathrm{qt}$ ) (Fig. 3). Choice of materials used for each container size was based on expected material durability, with gallon-container prototypes being made only of materials expected to be relatively durable to withstand the longer culture cycles required for nursery crops. The names, sources, and content of biobased polymers, fillers, and fibers used to form blends (mixture of two or more polymers), composites (compounded material containing polymer resin and non-resin fibrous additive), and coatings for prototypes in both phases of the study are itemized in Table 1. Information for commercially available biocontainers and petroleum-based control containers used in our trials are also included in Table 1. Materials and methods used to create the top-performing bioplastic-coated fiber container included in the phase-2 trial are available in McCabe et al. (2014). All prototypes except the coated-fiber container were injection-molded bioplastics or biocomposites. Specific blend ratios of bioplastic and biocomposite materials for injection-molded prototypes are on a per-weight basis and are indicated in figure captions and by their labels in the results section. Detailed descriptions of materials and methods used to create prototypes of injection-molded biocontainers are available in Srinivasan (2014). The phase-1 container labeled "TerraShell" is a commercially available bioplastic container made from wheat-based polymer by Summit Plastics Co. (Akron, OH). The relative shape, size, and appearance of phase- 1 containers are illustrated in Fig. 1. The 4.5-inch-diameter prototypes evaluated in phase- 2 trials (Fig. 2) were similar in size and shape to those shown from phase 1 , but had slightly thinner walls ( $1.3 \mathrm{~mm}$ compared with $2.0 \mathrm{~mm}$ ) to reduce the amount of material required, lower the cost per container, and potentially reduce the time required for biodegradation. Except for the two paper-fiber containers, all of the \#1 trade gallon containers evaluated in phase 2 were formed on a prototype mold (Fig. 3).

Container performance and plant quality during the phase-1 trial were evaluated after a 6-week greenhouseproduction cycle with 'Honeycomb' marigold (Tagetes patula), 'Autumn Bell' pepper (Capsicum annumm), 'Madness Red' petunia (Petunia $\times$ hybrida), 'St. John's Fire' salvia (Salvia splendens), and 'Rutgers' tomato 
Table 1. Source and production information for biobased polymers and fillers used to form blends and composites of prototype containers. Blend and composite ratios for each prototype evaluated in phase-1 and phase- 2 trials are shown in Tables 3 and 4, respectively. Source information for commercially available containers is also listed.

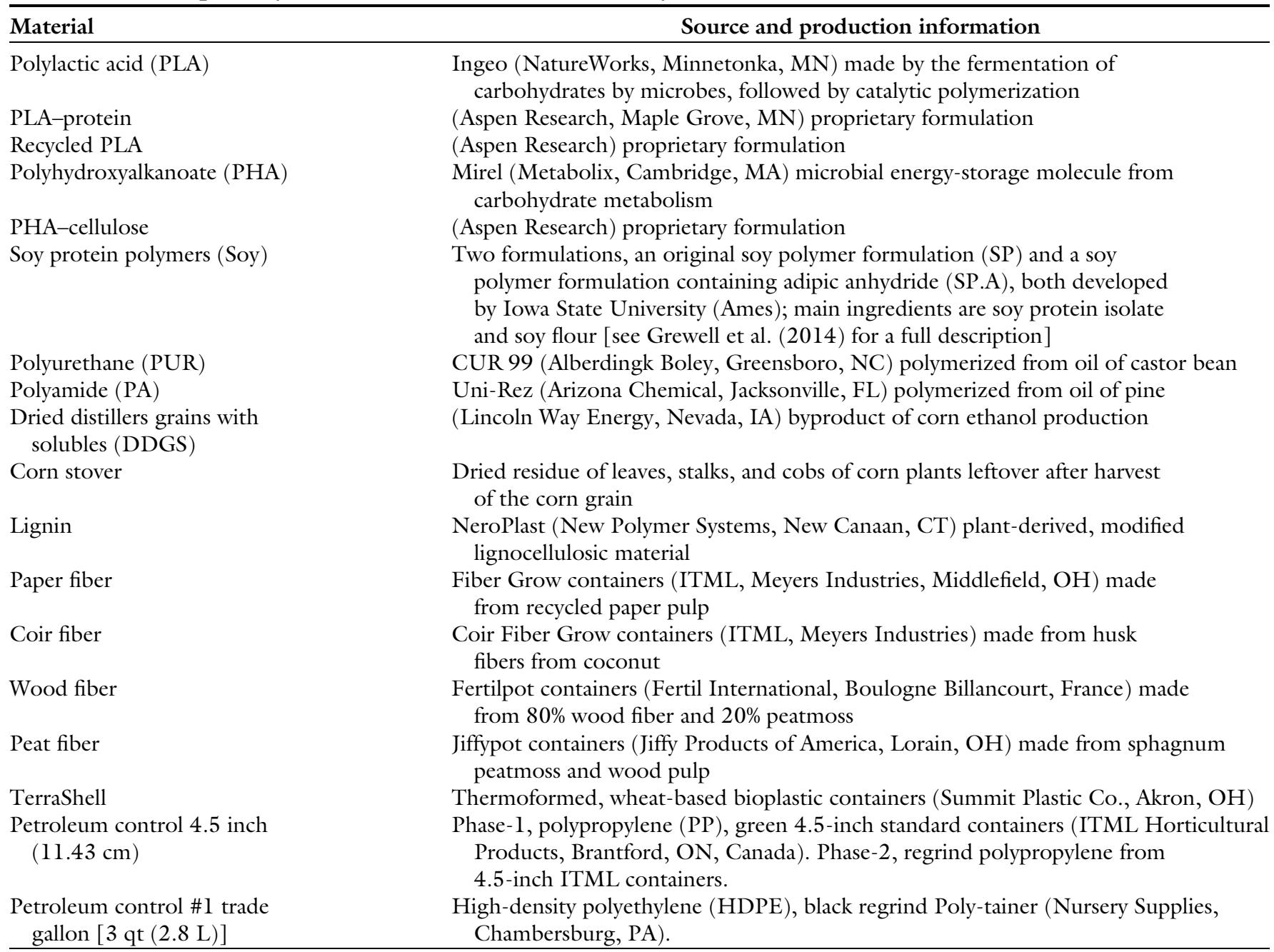

(Solanum lycopersicum). Experimental units (container + plant) were arranged 4 inches apart in a randomized complete block design ( $\mathrm{n}=5$ for container rating, and $n=70$ for plant quality) on expanded metal benches in a glassglazed greenhouse. Air temperature was maintained at $26 \pm 5{ }^{\circ} \mathrm{C}$, relative humidity ( $\mathrm{RH}$ ) ranged from $25 \%$ to $87 \%$ $($ mean $=59 \%)$, and the mean photosynthetically active radiation ( $P A R$ ) at $1200 \mathrm{HR}$ was $530 \mu \mathrm{mol} \cdot \mathrm{m}^{-2} \cdot \mathrm{s}^{-1}$. Container-plant units in all greenhouse trials were hand-irrigated as needed (visually assessed) and fertigated once per week with about $200 \mathrm{~mL}$ of $16.6 \mathrm{~N}-5 \mathrm{P}-16.3 \mathrm{~K}$ mixed to supply $\mathrm{N}$ at $150 \mathrm{mg} \cdot \mathrm{L}^{-1}$ (Peters Excel MultiPurpose and Cal-Mag; Everris International, Geldermalsen, The Netherlands).

Container performance and plant quality during the phase- 2 trials were evaluated after a 6-week greenhouse-production cycle (4.5inch-diameter containers), a 16-week greenhouse-production cycle (4.5inch-diameter containers, container performance only), and a 21-week nursery-production cycle (\#l trade gallon containers). Species produced in the 6-week trial of phase- 2 containers were 'Americana Dark Red' geranium (Pelargonium $\times$ hortorum), 'Honeycomb' marigold, 'Autumn Bell' pepper, and 'Oregon Spring' tomato that were grown by using the same experimental design $(\mathrm{n}=$ 13 for 6 -week container rating and $n$ $=52$ for plant quality) as in the phase1 trial, with air temperature that was maintained at $22 \pm 6{ }^{\circ} \mathrm{C}, \mathrm{RH}$ that ranged from $15 \%$ to $82 \%$ (mean = $46 \%)$, and $P A R$ at 1200 HR that averaged $421 \mu \mathrm{mol} \cdot \mathrm{m}^{-2} \cdot \mathrm{s}^{-1}$. Species produced in the 16-week trial were 'Synchro Pink' cyclamen (Cyclamen persicum), 'Jubilee Red' poinsettia
(Euphorbia pulcherrima), and 'Jaguar Red' gerbera (Gerbera jamesonii) that were grown by using the same experimental design $(\mathrm{n}=18$ for 16-week container rating) as in the phase-1 trial, with air temperature that was maintained at $24 \pm 5{ }^{\circ} \mathrm{C}$, $\mathrm{RH}$ that ranged from $24 \%$ to $84 \%$ (mean = $56 \%$ ), and $P A R$ at $1200 \mathrm{HR}$ that averaged $483 \mu \mathrm{mol} \cdot \mathrm{m}^{-2} \cdot \mathrm{s}^{-1}$. Species produced in the nursery trial were redosier dogwood (Cornus sericea), 'Elijah Blue' blue fescue (Festuca glauca), and white spruce (Picea glauca). Experimental units (container + plant) in the nursery trial were arranged 8 inches apart in a randomized complete block design $(n=8$ for container rating and $\mathrm{n}=32$ for plant quality) on expanded metal benches located outdoors and 4 inches above the ground over a gravel base. Container-plant units in the nursery trial were hand-irrigated as needed 


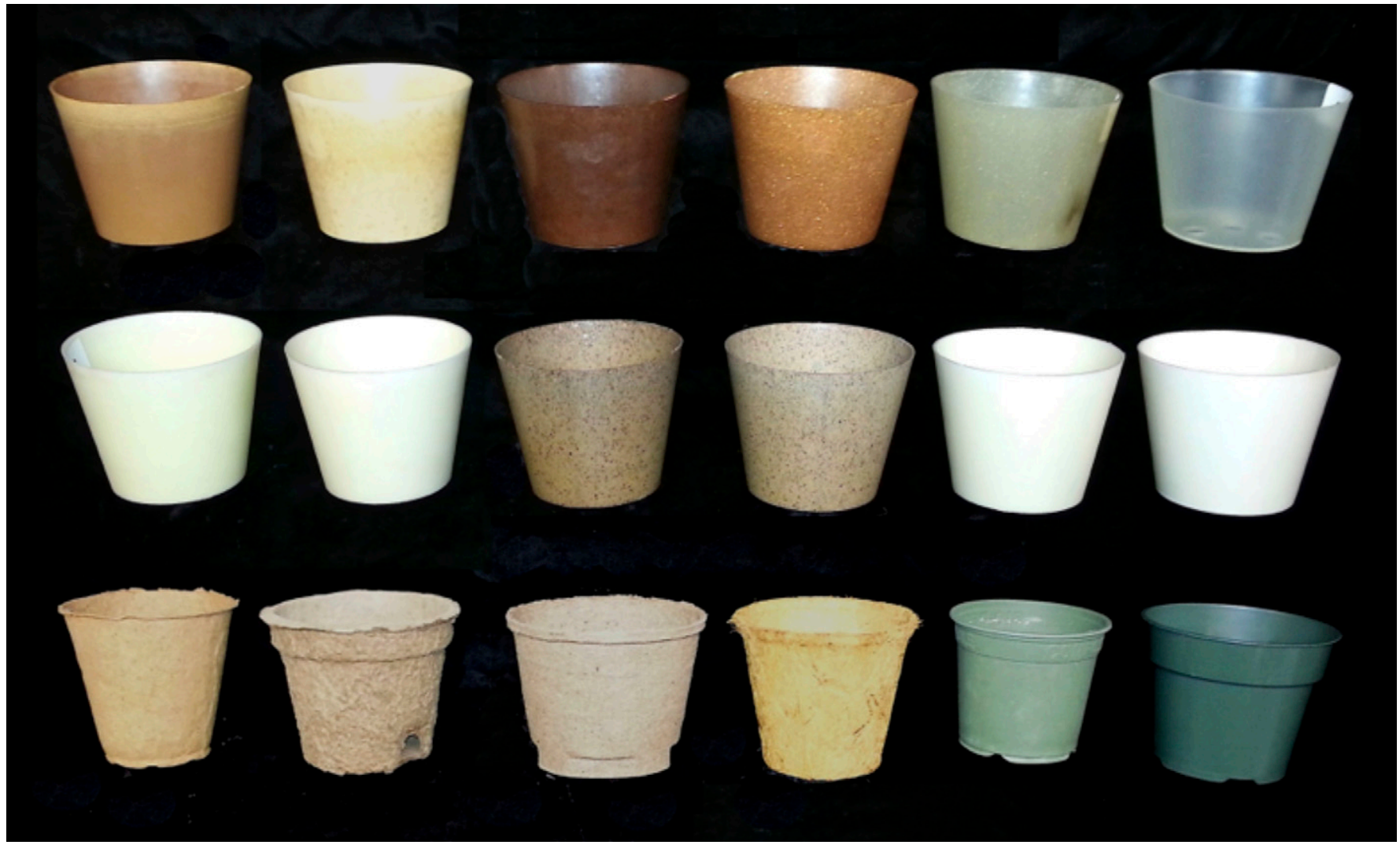

Fig. 1. Horticulture containers evaluated in phase-1 trials. Prototype containers had top diameters of 4.5 inches (11.43 cm) and volumes of $680 \mathrm{~cm}^{3}$. The petroleum control had a top diameter of 4.5 inches and a volume of $655 \mathrm{~cm}^{3}$. The top row shows prototype containers made of polylactic acid (PLA)-based blends and composites, which are from left to right: PLA-soy SP.A (50/50), PLA-soy SP (50/50), PLA-DDGS (90/10), PLA-corn stover (90/10), PLA-nanoclay (90/10), and PLA (100\%). The middle row shows prototype containers made of polyhydroxyalkanoate (PHA)-based blends and composites, which are from left to right: PHA P4010 (30\% starch), PHA P1008 (10\% starch), PHA P1004-DDGS (90/10), PHA P1003-DDGS (90/10), PHA P1004, and PHA P1003. The bottom row shows commercially available containers, which are from left to right: Wood fiber $\left(\right.$ volume $\left.=440 \mathrm{~cm}^{3}\right)$, Paper fiber $\left(\right.$ volume $\left.=600 \mathrm{~cm}^{3}\right)$, Peat fiber $\left(\right.$ volume $\left.=760 \mathrm{~cm}^{3}\right)$, Coir fiber $\left(\right.$ volume $\left.=610 \mathrm{~cm}^{3}\right)$, TerraShell [Summit Plastic Co., Akron, $\mathrm{OH}\left(\right.$ volume $\left.=473 \mathrm{~cm}^{3}\right)$ ], and Petroleum control [polypropylene $\left.(\mathrm{PP})\right]$. Specific blend ratios of bioplastic and biocomposite materials for injection-molded prototypes are on a per-weight basis; SP = soy polymer, SP.A = soy polymer with adipic anhydride, DDGS = dried distillers grains with solubles, PHA P4010 = PHA blend with $30 \%$ starch, PHA P1 008 = PHA blend with $10 \%$ starch, PHA P1003 and P1004 are pure PHA formulations; $1 \mathrm{~cm}^{3}=0.0610$ inch ${ }^{3}$.

(visually assessed) and received a onetime application of $7.5 \mathrm{~g} /$ container $14 \mathrm{~N}-6.1 \mathrm{P}-11.6 \mathrm{~K}$ controlled-release fertilizer (Osmocote Classic 14-1414, Everris International) directly after transplanting into the containers. Mean environmental conditions during the 21-week nursery trial were: temperature $=19.6^{\circ} \mathrm{C}, \mathrm{RH}=51 \%$, and $P A R$ at $1200 \mathrm{HR}=368 \mu \mathrm{mol} \cdot \mathrm{m}^{-2} \cdot \mathrm{s}^{-1}$.

Evaluations of container performance (container rating) were means of blind ratings by two experienced horticulturists and quantified the strength, durability, integrity, and aesthetic appearance of containers made of each material after use in crop-production cycles of 6,16 , or 21 weeks. On the basis of visible inspection and application of force by handling and squeezing of each container to assess the four performance parameters, experimental units were ascribed a rating of 0 to 5 , with 5 being best and 0 being worst/failed. Measurements of plant quality for each trial were combined measurements of plant health and size and were calculated as the product of the plant health rating (blind rating by two experienced horticulturists) and normalized three-dimensional shoot volume, then standardized to a scale of 0 to 100 ( $100=$ best, $0=$ worst $)$. Health ratings were on a scale of $0=$ worst $/$ dead to 5 = best. Indicators of poor health that resulted in lower ratings included chlorosis, necrosis, and stunted growth. Normalization of shoot volume was performed separately for each species to achieve a common range for data across species (Pyle, 1999).
We conducted biodegradation experiments in soil for periods of up to 1.5 years. Phase- 1 and phase- 2 short-term evaluations were conducted at two sites with dissimilar soil and climate in Iowa and Nevada (Table 2). In Iowa, the field plot was at a horticulture research farm of Iowa State University near Gilbert, where the soil was a Clarion loam, fineloamy, mixed, superactive, mesic Type Hapludoll. In Nevada, the field plot was at an agriculture research farm of the University of Nevada in Reno, where the soil was a Truckee silt loam, recent alluvial, Alluvial Humic Gley. The long-term trial was conducted at the site at Gilbert, IA, and consisted of evaluations after 6 months, 1 year, and 1.5 years. Samples for the trials were new, one-fourth-sized 


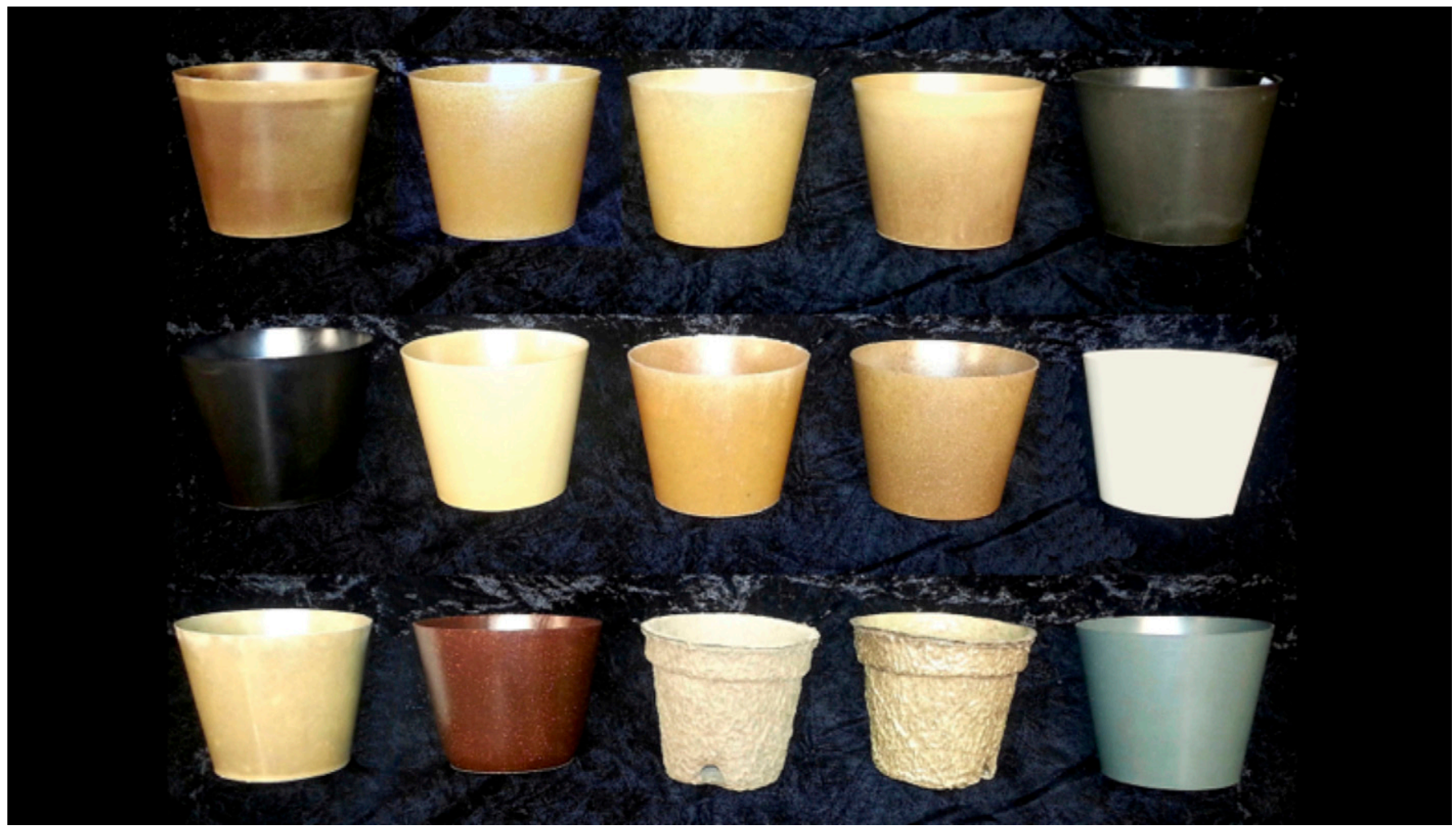

Fig. 2. Containers $[4.5$ inch $(11.43 \mathrm{~cm})]$ evaluated in phase-2 trials. All injection-molded containers had volumes of $680 \mathrm{~cm}^{3}$ and were formed on the same mold. The top row shows prototype containers from left to right: PLA-soy SP.A (50/50), PLAsoy SP.A (67/33), PLA-DDGS (80/20), PLA-soy-DDGS (60/30/10), and PLA-soy-lignin (70/30/10). The middle row shows prototype containers from left to right: PLA-lignin (80/20), PLA-protein (proprietary Aspen Research, Maple Grove, MN), PHA-soy SP.A (67/33), PHA-DDGS (80/20), and PHA P1008 (10\% starch). The bottom row shows left to right: PHA-cellulose (proprietary Aspen Research), Polyamide-DDGS $(70 / 30)$, uncoated Paper fiber $\left(\right.$ volume $\left.=600 \mathrm{~cm}^{3}\right)$, Paper fiber with two coats biobased polyurethane [PUR (volume $\left.=600 \mathrm{~cm}^{3}\right)$ ], and Petroleum control [polypropylene $\left.(\mathrm{PP})\right]$. Specific blend ratios of bioplastic and biocomposite materials for injection-molded prototypes are on a per-weight basis; PLA = polylactic acid, SP.A = soy polymer with adipic anhydride, soy = same as SP.A, DDGS = dried distillers grains with solubles, PHA = polyhydroxyalkanoate, PHA P1008 = PHA blend with $10 \%$ starch; $1 \mathrm{~cm}^{3}=0.0610 \mathrm{inch}^{3}$.

container pieces that were weighed, placed in nondegradable mesh bags, and buried 4 inches below the soil surface in a completely randomized design $(\mathrm{n}=3$ and $\mathrm{n}=4$ for each container material in phase- 1 and phase-2 trials, respectively). In Iowa, phase- 1 trials began 17 May 2012 and ended 1 Nov. 2012 for the 24-week trial. In Nevada, phase- 1 trials began 15 June 2012 and ended 30 Nov. 2012. In Iowa, phase- 2 trials began 25 May 2013 and ended 8 Nov. 2013 for the 24-week trial. In Nevada, phase-2 trials began 14 June 2013 and ended 2 Dec. 2013. Sample collections for the long-term trial of phase-1 materials in Iowa were 29 Nov. 2012, 17 May 2013, and 29 Nov. 2013 for the 6-month, 1-year, and 1.5-year evaluations, respectively.

Field plots were irrigated uniformly once per week by overhead irrigation with $\approx 1$ inch of water during each growing season (from beginning to end of short-term trials; from 17 May to 1 Nov. for the longterm trial). Details about soil and air temperatures during the trial and results of soil analyses are shown in Table 2. Samples of containermaterial pieces were collected from the soil after 24 weeks for the shortterm trials, and after 6 months, 1 year, and 1.5 years for the long-term trial. After removal from soil, samples in their mesh bags were washed with water under gentle agitation to remove remaining field soil, dried for $9 \mathrm{~d}$ at $33{ }^{\circ} \mathrm{C}$ and mean $\mathrm{RH}$ of $26 \%$ (Iowa), or oven-dried for $24 \mathrm{~h}$ at $55^{\circ} \mathrm{C}$ (Nevada), and held for $24 \mathrm{~h}$ in ambient conditions before weighing. Percentage degradation was calculated from weight lost during the degradation period.

Samples were tested for phytotoxicity before and after degradation in soil by using the standardized Organisation for Economic
Co-operation and Development terrestrial plant test of seedling emergence and seedling growth (Organisation for Economic Co-operation and Development, 2006). Tests were performed with 'Rutgers' tomato by grinding the materials of each container type into particles $\leq 1 \mathrm{~mm} \mathrm{di}^{-}$ ameter, mixing the ground material with soil at 1000 or $10,000 \mathrm{mg} \cdot \mathrm{kg}^{-1}$, and culturing seeds and seedlings in the media mixtures for a total of $27 \mathrm{~d}$ in a glass-glazed greenhouse by using a completely randomized design with replications of $\mathrm{n}=10$. Control units were grown in the same soil without addition of test materials. Mean environmental conditions during the 27- $\mathrm{d}$ experiment were: temperature $=$ $25.4^{\circ} \mathrm{C}, \mathrm{RH}=41 \%$, and $P A R$ at 1200 $\mathrm{HR}=515 \mu \mathrm{mol} \cdot \mathrm{m}^{-2} \cdot \mathrm{s}^{-1}$. Experimental units were evaluated for presence or absence of phytotoxic effects by measuring percentage of seedling emergence and seedling height, and by 


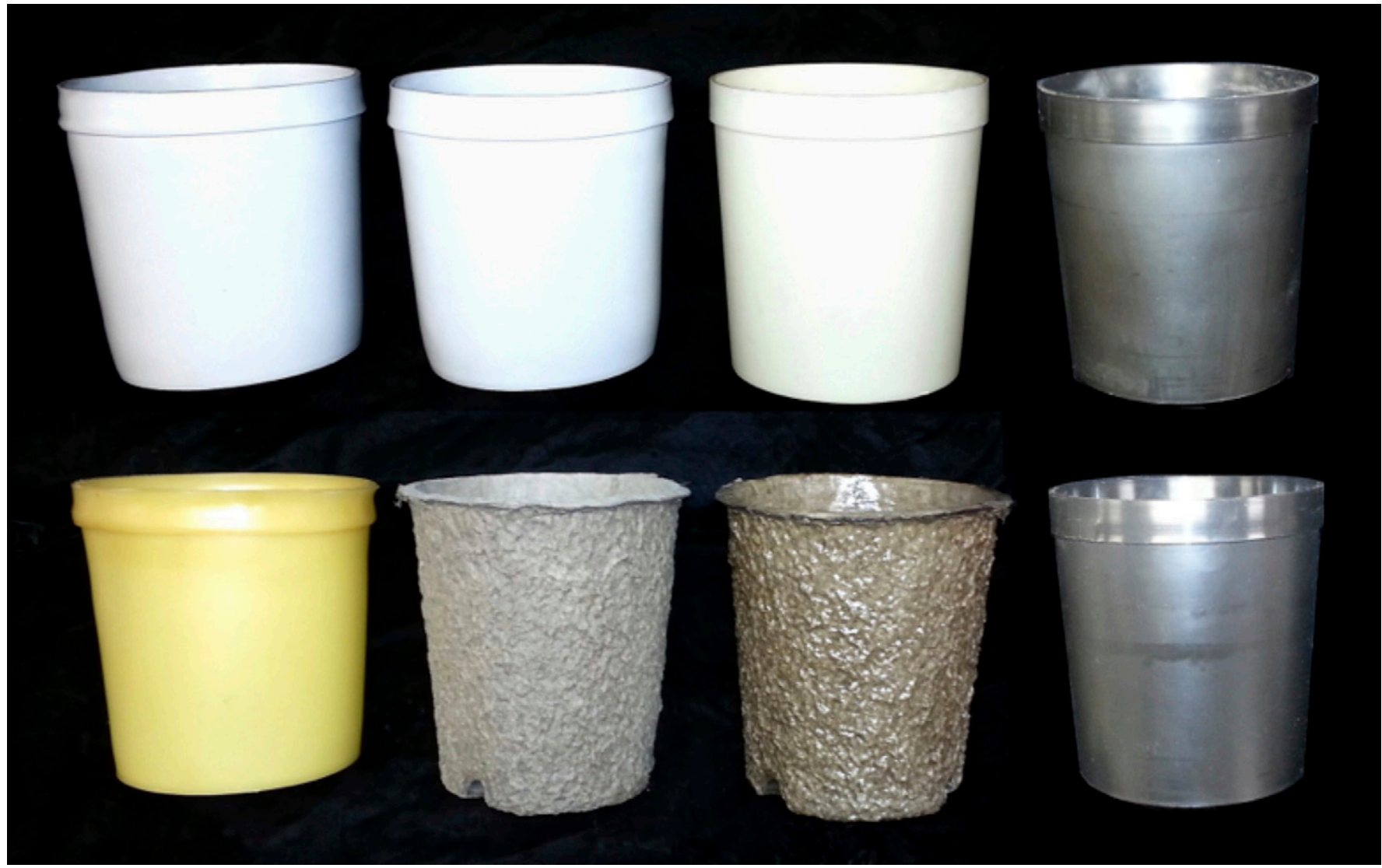

Fig. 3. Nursery containers evaluated in phase- 2 trials. All injection-molded containers were \# 1 trade gallon size [3 qt $(2.8 \mathrm{~L})$ ] and had top diameters of $16 \mathrm{~cm}\left[6.3\right.$ inches $\left(\right.$ volume $\left.\left.=2600 \mathrm{~cm}^{3}\right)\right]$. Prototype containers and the petroleum control were formed on the same mold. The \# 1 Paper-fiber containers had top diameters of $16 \mathrm{~cm}$ (volume $\left.=2660 \mathrm{~cm}^{3}\right)$. The top row shows prototype containers from left to right: Recycled PLA \# 1 (Aspen) (Aspen Research, Maple Grove, MN), Recycled PLA \# 2 (Aspen), PHA P1008 (10\% starch), and PHA-lignin (80/20). The bottom row shows left to right: prototype Polyamide-PLA (70/30), commercially available Paper fiber, Paper fiber with two coats biobased polyurethane (PUR), and Petroleum control [highdensity polyethylene (HDPE)]. Specific blend ratios of bioplastic and biocomposite materials for injection-molded prototypes are on a per-weight basis; PLA = polylactic acid, PHA = polyhydroxyalkanoate, PHA P1008 = PHA blend with $10 \%$ starch; $1 \mathrm{~cm}^{3}=0.0610$ inch $^{3}$.

visual inspection of seedlings for evidence of stunted growth, chlorosis, discoloration, mortality, or abnormal morphology (Organisation for Economic Co-operation and Development, 2006).

Statistical analysis. Data for all experiments were analyzed for main effects, interactions, and means separation by using SAS/STAT (version 9.1) or JMP Pro (version 1 1.0.0) statistical software (SAS Institute, Cary, NC). Means separation analyses were conducted by using TukeyKramer honest significant difference model $(P \leq 0.05)$. In biodegradation trials, the "difference" parameter was the simple mathematical difference in percentage degradation of each material type in the Nevada plot compared with its result in the Iowa plot. Differences were tested for significance by using the Student's $t$ test individually for each material type. The cumulative mean represents the calculated mean of the percentage degradation in Iowa and Nevada; it is designed as a means of comparison for overall degradation of materials across both sites. Results for container rating were not different across species in any of the trials; therefore, results for containers were combined across species to provide the mean for each container material. For the size component of the parameter of "plant quality," normalization was performed separately for each species to achieve a common range for size data across species (Pyle, 1999). Normalization of individual values was accomplished by using the formula: $\mathrm{a}+(\mathrm{X}-$ $\mathrm{A})(\mathrm{b}-\mathrm{a}) /(\mathrm{B}-\mathrm{A})$ where $\mathrm{A}=$ minimum of original data set, $B=$ maximum of original data set, $\mathrm{a}=$ minimum of normalized data set $(0), b=$ maximum of normalized data set (100), and $\mathrm{X}=$ the original individual value.

\section{Results and discussion}

The ideal biobased container would perform well under conditions of crop production, yet decompose within a reasonable time period in soil or when composted. It should function as well as the industry standard petroleum-based container, be easy to manufacture, have an aesthetically acceptable appearance, and be costcompetitive. Our study focuses on a few of these parameters, specifically the performance of several types of biobased containers and their biodegradation in soil. We evaluated a number of novel and existing biocontainers during greenhouse and nursery crop production and when buried in soil for up to 1.5 years in Iowa, and for 24 weeks in the diverse soils and 
Table 2. Mean daily soil temperature at 4 inches $(10.2 \mathrm{~cm})$, mean daily high and low air temperatures, and soil analyses for field trials evaluating the biodegradation in soil of bioplastic and biocomposite container prototypes and commercially available biocontainers. Biodegradation was evaluated at two sites with dissimilar soil and climate (Ames, IA and Reno, NV) in 2012 and 2013. Temperatures are shown as means for sequential 4-week periods and for the overall trial period of 24 weeks.

\begin{tabular}{|c|c|c|c|c|c|c|}
\hline \multirow[b]{2}{*}{ Container material } & \multicolumn{3}{|c|}{ Ames, IA, Mean daily temp $\left({ }^{\circ} \mathbf{C}\right)^{\mathrm{z}}$} & \multicolumn{3}{|c|}{ Reno, NV, Mean daily temp $\left({ }^{\circ} \mathrm{C}\right)$} \\
\hline & Soil & Air high & Air low & Soil & Air high & Air low \\
\hline \multicolumn{7}{|l|}{2012 (Phase 1$)$} \\
\hline 4 to 8 weeks & 24.7 & 29.4 & 19.2 & 20.5 & 31.9 & 10.2 \\
\hline 8 to 12 weeks & 26.9 & 31.2 & 19.5 & 20.6 & 33.3 & 10.3 \\
\hline 12 to 16 weeks & 21.5 & 26.9 & 15.9 & 18.3 & 29.5 & 6.4 \\
\hline Mean for 24 weeks & 20.2 & 24.9 & 13.4 & 16.6 & 26.7 & 5.2 \\
\hline \multicolumn{7}{|l|}{2013 (Phase 2) } \\
\hline 0 to 4 weeks & 18.9 & 23.4 & 13.7 & 15.9 & 27.8 & 7.7 \\
\hline 4 to 8 weeks & 25.9 & 29.7 & 18.5 & 18.8 & 33.0 & 11.9 \\
\hline 8 to 12 weeks & 24.9 & 26.2 & 14.4 & 17.7 & 30.8 & 8.4 \\
\hline Soil analysis & Nitrogen $\left(\mathrm{mg} \cdot \mathrm{kg}^{-1}\right)^{\mathrm{z}}$ & Phosphorus $\left(\mathrm{mg} \cdot \mathrm{kg}^{-1}\right)$ & Potassium $\left(\mathrm{mg} \cdot \mathrm{kg}^{-1}\right)$ & $\mathrm{pH}$ & Organic matter (\%) & \\
\hline Ames, IA & 1300 & 43 & 159 & 6.7 & 2.8 & \\
\hline Reno, NV & 48.8 & 33 & 791 & 7.7 & 0.3 & \\
\hline
\end{tabular}

${ }^{z}\left(1.8 \times{ }^{\circ} \mathrm{C}\right)+32={ }^{\circ} \mathrm{F}, 1 \mathrm{mg} \cdot \mathrm{kg}^{-1}=1 \mathrm{ppm}$.

climates of Iowa and Nevada. Depending on the blend or composite material, most of the PLA- and PHA-based containers performed as well as petroleum-based containers for production of greenhouse and nursery crops, and some produced plants of even better quality than those produced in standard petroleum-plastic containers. Many of the blends and composites of these materials also degraded in soil at an acceptable rate in both Iowa and Nevada.

In trials of phase- 1 materials, all but two of the prototype containers received the highest container rating possible, ratings equal with those of the petroleum-based container, demonstrating that most of the PLA- and PHA-based materials possessed ample durability (strength, integrity, and aesthetically pleasing appearance after use) for production of short-cycle greenhouse crops (Table 3). Although prototypes made of the two PLA-Soy blends received slightly lower container ratings than petroleum containers and the other prototypes, they scored higher than the commercially available wood-, peat-, and coir-fiber containers, and they produced plants of higher quality than any of the other containers in the trial (Table 3 ). We attribute the greater quality of plants grown in PLA-Soy containers to the fertilizer effect provided by the soy component of the blended plastic, a function first reported by Schrader et al. (2013). Another trend in the performance of the phase-1 prototypes was that plants grown in PLA-based containers were generally of higher quality than those grown in the petroleumbased control container, PHA-based containers, and the commercially available biocontainers, though not all were statistically different at $\alpha=0.05$. Of the commercially available biocontainers evaluated in the trial, the TerraShell and paper-fiber containers performed better than the wood-, peat-, and coir-fiber containers for the parameters of container rating and plant quality, and were not different from the petroleum control during the 6-week trial (Table 3).

The results of biodegradation trials with phase-1 materials indicate that many of the injection-molded bioplastic blends and composites can biodegrade in soil within an acceptable time frame. Although bioplastic samples of pure PLA and pure PHA (Pl003 and P1004) biodegraded slowly $(3 \%$ to $7 \%)$ or very slowly $(<3 \%)$ over 24 weeks depending on the material and trial site, composites containing these materials and a biobased, fibrous filler (DDGS or corn stover) at a ratio of $90 / 10$ biodegraded at a faster rate, between $11 \%$ and $43.3 \%$ in 24 weeks depending on the material and trial site (Table 3 ). The rate of biodegradation of each container material was either not different in Nevada compared with Iowa or was slower in Nevada (see results for "difference" in Table 3). Two factors that may have contributed to the lower rate of biodegradation for many of the material types in Nevada were the lower soil temperatures and the less favorable soil nutrient, $\mathrm{pH}$, and organic matter characteristics of the Nevada soils (Table 2), factors that are often correlated with lower activity of soil microorganisms and lower rates of decomposition (Bronick and Lal, 2005). The two materials that showed the greatest difference in biodegradation at the Iowa and Nevada sites were the composites PHA P1004-DDGS and PHA Pl003-DDGS, which biodegraded at $32.3 \%$ and $24.8 \%$ points less in Nevada, respectively. Prototype materials PLA-Soy SP.A, PLA-Soy SP, and PHA P4010, along with commercially available wood-fiber and paper-fiber containers showed the greatest rates of biodegradation 
Table 3. Container performance in a 6-week crop cycle and biodegradation in soil of plant-container samples made from phase-1 bioplastics and biocomposites or commercially available container materials and buried in soil for 24 weeks. Results for container rating and plant quality represent the condition of containers and plants (marigold, petunia, salvia, pepper, and tomato) after production to a marketable size. Biodegradation was evaluated at two sites with dissimilar soil and climate (Ames, IA and Reno, NV) in 2012. Percentage degradation of materials in each trial plot was calculated as the percentage weight loss of material samples during 24 weeks in soil. The "Difference" parameter is the simple mathematical difference in percentage degradation of each material type in the Nevada plot compared with its result in the Iowa plot.

\begin{tabular}{|c|c|c|c|c|c|c|}
\hline \multirow[b]{2}{*}{ Container material $^{\mathrm{z}}$} & \multirow{2}{*}{$\begin{array}{c}\text { Container rating } \\
(0 \text { to } 5)^{\mathrm{y}}\end{array}$} & \multirow{2}{*}{$\begin{array}{l}\text { Plant quality } \\
(0 \text { to } 100)^{\mathrm{x}}\end{array}$} & \multicolumn{4}{|c|}{ Degradation in soil (\%) } \\
\hline & & & Iowa plot & Nevada plot & Difference & Cumulative mean \\
\hline \multicolumn{7}{|l|}{ PLA-based blends or composites } \\
\hline PLA-soy SP $(50 / 50)$ & $4.5 \mathrm{~b}$ & $88 \mathrm{~b}$ & $50.6 \mathrm{ab}$ & $44.2 \mathrm{a}$ & $-6.4^{* *}$ & 47.4 \\
\hline PLA-DDGS $(90 / 10)$ & $5.0 \mathrm{a}$ & $70 \mathrm{c}-\mathrm{e}$ & $17.9 \mathrm{e}-\mathrm{g}$ & $14.2 \mathrm{~b}$ & $-3.7 \mathrm{NS}$ & 16.0 \\
\hline PLA-corn stover $(90 / 10)$ & $5.0 \mathrm{a}$ & $73 \mathrm{~cd}$ & $13.6 \mathrm{e}-\mathrm{g}$ & $12.1 \mathrm{bc}$ & $-1.5 * *$ & 12.9 \\
\hline \multicolumn{7}{|l|}{ PHA-based blends or composites } \\
\hline PHA P4010 (30\% starch) & $5.0 \mathrm{a}$ & $56 \mathrm{gh}$ & $58.1 \mathrm{a}$ & 38.6 a & $-19.5^{*}$ & 48.3 \\
\hline PHA P1008 (10\% starch) & $5.0 \mathrm{a}$ & $68 \mathrm{de}$ & $18.8 \mathrm{e}-\mathrm{g}$ & $9.4 \mathrm{bc}$ & $-9.4^{* *}$ & 14.1 \\
\hline PHA P1004-DDGS $(90 / 10)$ & $5.0 \mathrm{a}$ & $62 \mathrm{e}-\mathrm{h}$ & $43.3 \mathrm{a}-\mathrm{c}$ & $11.0 \mathrm{bc}$ & $-32.3 * * *$ & 27.1 \\
\hline PHA P1003-DDGS $(90 / 10)$ & $5.0 \mathrm{a}$ & $59 \mathrm{f}-\mathrm{h}$ & $36.1 \mathrm{~b}-\mathrm{d}$ & $11.3 \mathrm{bc}$ & $-24.8^{* *}$ & 23.7 \\
\hline Paper fiber & $5.0 \mathrm{a}$ & $60 \mathrm{f}-\mathrm{h}$ & $53.0 \mathrm{ab}$ & $47.6 \mathrm{a}$ & $-5.4 \mathrm{NS}$ & 50.3 \\
\hline Peat fiber & $3.4 \mathrm{e}$ & $43 \mathrm{i}$ & $31.3 \mathrm{c}-\mathrm{e}$ & $43.7 \mathrm{a}$ & $12.4 \mathrm{NS}$ & 37.5 \\
\hline Coir fiber & $3.6 \mathrm{~d}$ & $54 \mathrm{~h}$ & $28.0 \mathrm{~d}-\mathrm{f}$ & $12.7 \mathrm{bc}$ & $-15.3^{\star}$ & 20.3 \\
\hline TerraShell $^{\mathrm{u}}$ & $5.0 \mathrm{a}$ & $63 \mathrm{e}-\mathrm{g}$ & $10.3 \mathrm{f}-\mathrm{h}$ & $3.1 \mathrm{bc}$ & $-7.2 * * *$ & 6.7 \\
\hline Petroleum control (PP) & $5.0 \mathrm{a}$ & $66 \mathrm{~d}-\mathrm{f}$ & $0.0 \mathrm{~h}$ & $0.0 \mathrm{c}$ & $0.0 \mathrm{NS}$ & 0.0 \\
\hline \multicolumn{7}{|c|}{ 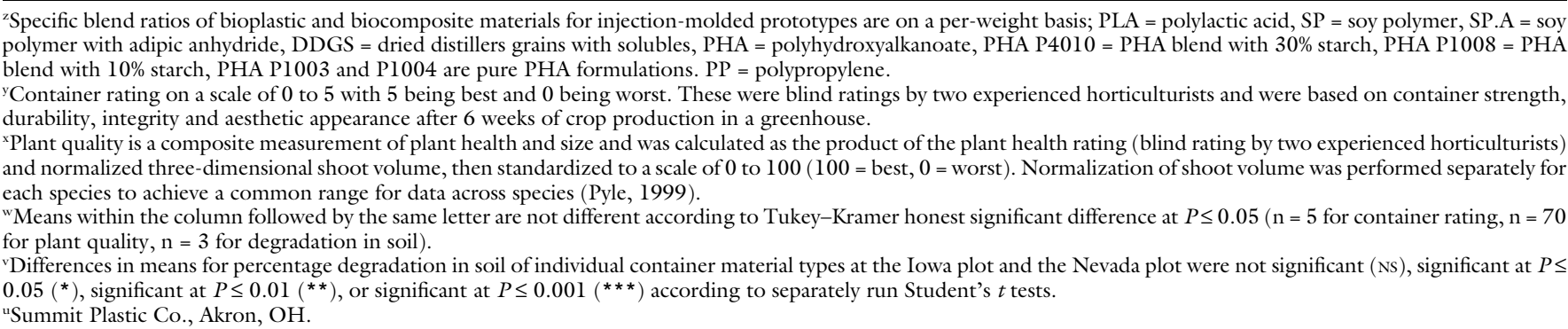 } \\
\hline
\end{tabular}

in both Iowa and Nevada soils (Table 3 ). The strong increase in the rate of biodegradation for the PLA-Soy blends compared with that of pure PLA is consistent with results reported by Yang et al. (2015) and supports their conclusion that blending soy polymer with PLA can be a useful method for improving the biodegradability of PLA-based materials. The commercially available, wheat polymer-based TerraShell pot degraded at a slower rate than many of the bioplastic and biocomposite prototypes and the commercially available wood-, paper-, and peat-fiber containers (Table 3 ). As expected, the petroleum control showed no measurable weight loss from biodegradation.

Except for the PLA-Soy SP.A $(50 / 50)$, the PHA Pl008, and the petroleum control, all of the materials in the phase- 2 evaluations were different from those of phase 1 , and most of the newer blends and composites were formulated based on results of phase-1 trials to improve biodegradation rate or durability during crop production or to lower material costs. Many of the new biocomposite formulations contained a higher percentage of biobased, fibrous filler material than those of phase 1, and some contained two types of biocomposite materials in their formulation. In general, the increased content of filler material in the biocomposite appeared to increase the rate of biodegradation in soil, but it also appeared to reduce the overall durability (container rating) of many of the PLA- and PHA-based biocomposites during crop production (Table 4). Another factor that likely contributed to lower durability and increased biodegradation of some of the biocomposites was the reduced wall thickness of 4.5 -inch containers in phase 2 compared with those in phase-1 trials.

In phase-2 greenhouse trials with 4.5-inch containers, a few of the prototype containers were very durable and showed container ratings that were not different from those of petroleum-based containers in either the 6- or 16-week greenhouse trials (Table 4). These durable prototypes were PLA-DDGS $(80 / 20)$, PLALignin $(80 / 20)$, PHA-DDGS $(80 /$ 20), and PHA Pl008. Although these were the most durable of the prototypes that were formed into 4.5inch containers, and they produced plants of similar quality to those in the petroleum control, they did not 
Table 4. Container performance during crop production and biodegradation in soil of plant container samples made from phase- 2 bioplastics or biocomposites and buried in soil for 24 weeks. Results for container rating and plant quality represent the condition of containers and plants after production to a marketable size in a 6-week (geranium, marigold, pepper, and tomato), 16-week (cyclamen, gerbera, and poinsettia), or 21 -week crop cycle (fescue, redosier dogwood, and white spruce). Biodegradation was evaluated at two sites with dissimilar soil and climate (Ames, IA and Reno, NV) in 2013. Percentage degradation of materials in each trial plot was calculated as the percentage weight loss of material samples during 24 weeks in soil. The "Difference" parameter is the simple mathematical difference in percentage degradation of each material type in the Nevada plot compared with its result in the Iowa plot.

\begin{tabular}{|c|c|c|c|c|c|c|c|}
\hline \multirow[b]{2}{*}{${\text { Container } \text { material }^{\mathrm{z}}}$} & \multicolumn{2}{|c|}{ Container rating $(0 \text { to } 5)^{\mathrm{y}}$} & \multirow[b]{2}{*}{$\begin{array}{l}\text { Plant quality } \\
(0 \text { to } 100)^{\mathrm{x}}\end{array}$} & \multicolumn{4}{|c|}{ Degradation in soil (\%) } \\
\hline & $6 \mathrm{wk}$ & $\begin{array}{l}16 \text { or } \\
21 \mathrm{wk} \\
\end{array}$ & & $\begin{array}{c}\text { Iowa } \\
\text { plot }\end{array}$ & $\begin{array}{c}\text { Nevada } \\
\text { plot }\end{array}$ & Difference & $\begin{array}{c}\text { Cumulative } \\
\text { mean }\end{array}$ \\
\hline \multicolumn{8}{|l|}{ PLA-based blends or composites } \\
\hline PLA-soy SP.A $(50 / 50)$ & $3.9 \mathrm{f}^{\mathrm{w}}$ & $2.7 \mathrm{e}^{\mathrm{v}}$ & $98 \mathrm{ab}^{\mathrm{u}}$ & $45.2 \mathrm{c}^{\mathrm{w}}$ & $45.1 \mathrm{bc}^{\mathrm{w}}$ & $-0.1 \mathrm{NS}^{\mathrm{t}}$ & 45.2 \\
\hline PLA-soy SP.A (67/33) & $4.4 \mathrm{e}$ & $4.7 \mathrm{ab}$ & $88 \mathrm{bc}$ & $29.0 \mathrm{de}$ & $29.2 \mathrm{~d}-\mathrm{g}$ & $0.2 \mathrm{NS}$ & 29.1 \\
\hline PLA-DDGS $(80 / 20)$ & $5.0 \mathrm{a}$ & $4.7 \mathrm{ab}$ & $74 \mathrm{~cd}$ & $10.5 \mathrm{~g}$ & $11.3 \mathrm{~h}-\mathrm{j}$ & $0.8 \mathrm{NS}$ & 10.9 \\
\hline PLA-lignin $(80 / 20)$ & $5.0 \mathrm{a}$ & $5.0 \mathrm{a}$ & $80 \mathrm{c}$ & $0.2 \mathrm{~h}$ & $1.0 \mathrm{ij}$ & $0.7^{*}$ & 0.6 \\
\hline PLA-protein $(\text { Aspen })^{\mathrm{s}}$ & $4.5 \mathrm{de}$ & $3.1 \mathrm{~d}$ & $100 \mathrm{a}$ & $34.7 \mathrm{~d}$ & $32.5 \mathrm{c}-\mathrm{f}$ & $-2.1 \mathrm{NS}$ & 33.6 \\
\hline Recycled PLA \# 1 (Aspen) & - & $5.0 \mathrm{~A}$ & $90 \mathrm{~A}$ & $0.2 \mathrm{~h}$ & $0.4 \mathrm{j}$ & $0.2 *$ & 0.3 \\
\hline Recycled PLA \# 2 (Aspen) & - & $5.0 \mathrm{~A}$ & $93 \mathrm{~A}$ & $0.2 \mathrm{~h}$ & $0.3 \mathrm{j}$ & $0.2 \mathrm{NS}$ & 0.2 \\
\hline \multicolumn{8}{|l|}{ PHA-based blends or composites } \\
\hline PHA-soy SP.A $(67 / 33)$ & $4.6 \mathrm{~cd}$ & Failed & $47 \mathrm{gh}$ & $90.3 \mathrm{~b}$ & 87.9 a & $-2.5 \mathrm{NS}$ & 89.1 \\
\hline PHA-lignin $(80 / 20)$ & - & $5.0 \mathrm{~A}$ & $96 \mathrm{~A}$ & $4.0 \mathrm{~h}$ & $5.8 \mathrm{ij}$ & $1.8 \mathrm{NS}$ & 4.9 \\
\hline \multicolumn{8}{|l|}{ Polyamide blends or composites } \\
\hline Polyamide-DDGS $(70 / 30)$ & $3.1 \mathrm{~g}$ & $3.5 \mathrm{c}$ & $68 \mathrm{~cd}$ & $18.0 \mathrm{f}$ & $14.9 \mathrm{~g}-\mathrm{i}$ & $-3.1^{*}$ & 16.5 \\
\hline Polyamide-PLA $(70 / 30)$ & - & $5.0 \mathrm{~A}$ & $100 \mathrm{~A}$ & $0.3 \mathrm{~h}$ & $0.2 \mathrm{j}$ & $-0.2 \mathrm{NS}$ & 0.3 \\
\hline Polyamide-lignin $(70 / 30)$ & - & - & - & $1.0 \mathrm{~h}$ & $0.8 \mathrm{ij}$ & $-0.2 \mathrm{NS}$ & 0.9 \\
\hline \multicolumn{8}{|l|}{ Paper fiber } \\
\hline Uncoated & $4.6 \mathrm{~cd}$ & $4.5 \mathrm{~b}, 2.5 \mathrm{C}$ & 42 h, $77 \mathrm{~A}$ & $11.9 \mathrm{fg}$ & $54.4 \mathrm{~b}$ & $42.5 * * *$ & 33.2 \\
\hline With two coats PUR & $4.9 \mathrm{ab}$ & $4.5 \mathrm{~b}, 4.3 \mathrm{~B}$ & $67 \mathrm{de}, 83 \mathrm{~A}$ & $11.2 \mathrm{~g}$ & $29.2 \mathrm{~d}-\mathrm{g}$ & $18.0^{*}$ & 20.2 \\
\hline Petroleum control (PP) & $5.0 \mathrm{a}$ & $5.0 \mathrm{a}$ & $77 \mathrm{c}$ & $0.1 \mathrm{~h}$ & $0.7 \mathrm{ij}$ & $0.6 \mathrm{NS}$ & 0.4 \\
\hline Petroleum control (HDPE) & - & $5.0 \mathrm{~A}$ & $99 \mathrm{~A}$ & $0.0 \mathrm{~h}$ & $0.1 \mathrm{j}$ & $0.1 \mathrm{NS}$ & 0.0 \\
\hline
\end{tabular}

${ }^{\mathrm{z}}$ Specific blend ratios of bioplastic and biocomposite materials for injection-molded prototypes are on a per-weight basis; PLA = polylactic acid, SP.A = soy polymer with adipic anhydride, soy $=$ same as SP.A, DDGS $=$ dried distillers grains with solubles, PHA = polyhydroxyalkanoate, PHA P1008 $=$ PHA blend with $10 \%$ starch, PUR = bio-based polyurethane, $\mathrm{PP}=$ polypropylene, $\mathrm{HDPE}=$ high-density polyethylene.

${ }^{y}$ Container rating on a scale of 0 to 5 with 5 being best and 0 being worst. These were blind ratings by two experienced horticulturists and were based on container strength, durability, integrity and aesthetic appearance after the designated time period of crop production in a greenhouse or nursery trial.

xPlant quality is a composite measurement of plant health and size and was calculated as the product of the plant health rating (blind rating by two experienced horticulturists) and normalized three-dimensional shoot volume, then standardized to a scale of 0 to 100 ( $100=b e s t, 0=$ worst $)$. Normalization of shoot volume was performed separately for each species to achieve a common range for data across species (Pyle, 1999). Results followed by an uppercase letter are from a 21 -week nursery trial with \#1 trade gallon [3 qt $(2.8 \mathrm{~L})]$ containers. Results followed by a lowercase letter are from a 6-week greenhouse trial with 4.5 -inch $(11.43 \mathrm{~cm})$ standard containers.

w Means within the column followed by the same letter are not different according to Tukey-Kramer honest significant difference (HSD) at $P \leq 0.05$ (n $=13$ for 6 -week container rating, $\mathrm{n}=4$ for degradation in soil).

${ }^{\mathrm{v}}$ Means within the column followed by the same uppercase letter (\#l trade gallon container, 21 -week trial) or same lowercase letter (4.5-inch standard container, 16-week trial) are not different according to Tukey-Kramer HSD $(P \leq 0.05, \mathrm{n}=18$ for 16 -week container rating, $\mathrm{n}=8$ for 21 -week container rating, $\mathrm{n}=52$ for 6 -week plant quality, $\mathrm{n}=32$ for 21 -week plant quality). Results labeled as "Failed" received this designation when all containers made of that material lacked suitable integrity to surround the root medium and showed open cracks of at least $5 \mathrm{~mm}$ wide and $50 \mathrm{~mm}$ long $(1 \mathrm{~mm}=0.0394$ inch).

"Means within the column followed by the same uppercase letter (\#l trade gallon container, 21 -week trial) or same lowercase letter (4.5-inch standard container, 6-week trial) are not different according to Tukey-Kramer HSD at $P \leq 0.05$ ( $\mathrm{n}=52$ for 6 -week plant quality, $\mathrm{n}=32$ for 21 -week plant quality).

${ }^{t}$ Differences in means for percentage degradation in soil of individual container material types at the Iowa plot and the Nevada plot were not significant (Ns), significant at $P \leq$ $0.05(*)$, significant at $P \leq 0.01\left(^{* *}\right)$, or significant at $P \leq 0.001(* *)$ according to separately run Student's $t$ tests.

sAspen Research, Maple Grove, MN.

produce the highest quality plants of the trial. Plants grown in prototype containers made of PLA-Soy SP.A (50/50), PLA-Soy SP.A $(67 / 33)$, PLA-Soy-DDGS, PLA-Soy-Lignin, PLA-Protein, and PHA-Cellulose scored the highest for plant quality and were superior to those grown in the control containers (Table 4). Each of these prototypes, except those made of PLA-Soy-Lignin and
PHA-Cellulose, were sufficiently durable (acceptable container rating) for the 6-week production cycle, and the prototypes made of PLA-Soy SP.A $(67 / 33)$ and PLA-Soy-DDGS $(60 /$ $30 / 10$ ) were reasonably durable during the 16-week greenhouse trial. All of the 4.5-inch container prototypes tested were considered sufficiently durable for crop cycles of at least 6 weeks, except those made of
PLA-Soy-Lignin or PHA-Cellulose. Most of the injection-molded prototypes performed as well as or better than the commercially available (uncoated) paper-fiber containers during crop production, and they biodegraded at a similar or faster rate in soil. The paper-fiber container performed better when coated with biobased polyurethane, and coating the container with biopolymer made it better than some 
of the prototypes for measures of both container rating and plant quality (Table 4).

In general, the 4.5-inch containers that showed the greatest durability during greenhouse trials (PLADDGS, PLA-Lignin, PHA P1008) showed slow rates of biodegradation in soil, and containers that biodegraded at a very fast rate (PHA-Soy, PHA-Cellulose) showed poor durability in greenhouse trials (Table 4). Of the PLA-based blends and composites, all of the prototypes that included soy polymer biodegraded at relatively high rates during their 24 weeks in soil, results consistent with those of phase-1 trials. Samples of PLA-DDGS material degraded at a faster rate than pure PLA, but results with this composite were slightly different from those of phase 1 in that the improvement in biodegradability from the added DDGS was not proportional to the amount of DDGS included. PLA-DDGS from phase 1, which contained DDGS at $10 \%$ by weight, degraded an average of $16 \%$ (Table 3), but the PLA-DDGS from phase 2, which contained DDGS at $20 \%$ by weight, degraded an average of only $10.9 \%$ (Table 4 ). Another interesting result with PLA-based composites in phase 2 was the lack of biodegradation of the PLA-Lignin prototype. Although lignin is considered a biobased, fibrous filler, it does not increase the biodegradability of PLA-based compounds in the way that was demonstrated with composites containing DDGS or corn stover. This result is not altogether surprising because lignin, although it is biobased and found naturally in the environment, is known to resist biodegradation because of its unique and complex molecular structure (Martínez et al., 2005).

Two of the PHA-based composites, PHA-Cellulose and PHA-Soy SP.A $(67 / 33)$, showed the greatest rates of biodegradation of all the materials in our trials, with mean biodegradation rates in soil of $100 \%$ and $89 \%$ within 24 weeks, respectively (Table 4). Although this demonstrates the potential to use cellulose and soy ingredients to increase the biodegradation rate of injectionmoldable PHA-based materials, the blend ratios used for prototypes in this trial were excessive for successful function during greenhouse production. Another interesting result with the PHA-Soy SP.A $(67 / 33)$ prototype was the absence of a beneficial fertilizer effect with this material, which contained the same soy polymer that produced a fertilizer effect when blended with PLA. While prototypes of PLA-Soy SP.A (67/ 33 ) produced plants that were among the highest quality of the trial, plants grown in prototypes made of PHASoy SP.A $(67 / 33)$ were among the lowest quality of the trial. Other PHA-based prototypes, PHA-DDGS and PHA Pl008, biodegraded at relatively high rates, were durable in greenhouse cycles of 6 and 16 weeks, and produced plants of acceptable quality (Table 4).

Our short-term degradation trials were conducted in two diverse climates to better assess the biodegradability of containers across a range of conditions. As seen with phase-1 trials, there were differences in the rates of biodegradation in Iowa and Nevada soils for some of the material types (Table 4), but many of the results of comparisons between the two sites during phase- 2 trials were not consistent with results obtained during phase-1 trials, even though the phase- 1 and phase- 2 trials were performed in the same general areas in each state and each year. The most notable change from phase 1 to phase 2 was the increased rate of biodegradation for PHA-based materials in Nevada (Tables 3 and 4) during phase 2 . During phase- 1 trials, every PHAbased material biodegraded more slowly in Nevada than it did in Iowa, and all of these differences were significant at an $\alpha$ of 0.05 or lower. During phase- 2 trials, biodegradation of PHA-based materials in Nevada increased enough that only one difference comparison was significant, and that comparison showed biodegradation of PHA P1008 at a greater rate in Nevada than in Iowa. Examination of the environmental data from the two trial seasons (Table 2) provides no clear explanation for the change in biodegradation dynamics, illustrating that rates of biodegradation in soil of biocontainer materials will likely vary from location to location and from season to season because of factors and interactions that are difficult to quantify. It is fairly certain that temperatures, moisture levels, and the types and abundance of local microorganisms in the soil play a strong role in the rate and effectiveness of biodegradation (Li et al., 2014), but our results in two different climates over two seasons suggest that local soil and climatic conditions may not have a consistent effect on the biodegradation rates of these materials.

Because most nursery species require longer crop cycles than those of common greenhouse species, the biobased materials evaluated as prototypes of \#l trade gallon containers in phase-2 trials were selected based on their known potential for durability. The durable character of these bioplastics and biocomposites was confirmed by our nursery trials and resulted in the highest container ratings possible (5) for all of the prototype containers after 21 weeks of nursery production, ratings equal to that of the petroleum control (Table 4, means followed by uppercase letters). Described qualitatively, we observed no change in coloring, outer surface texture, strength, or general appearance of \#l trade gallon container prototypes made of Recycled PLA \#1, Recycled PLA \#2, PHA P1008, PHA-Lignin $(80 / 20)$, or PolyamidePLA $(70 / 30)$ during the 21-week crop cycle. This was not the case for the commercially available (uncoated) paper-fiber container, which showed significant deterioration during the trial. Coating the paper-fiber nursery container with biopolymer improved its durability, but did not increase its container rating to the level achieved by the injection-molded prototypes or the control (Table 4, means followed by uppercase letters). In the nursery trial, material type had little to no effect on plant quality, which was consistently high for plants grown in all of the nursery containers in the trial. The biodegradation rates were very low (less than $5 \%$ in 24 weeks) for all of the gallon bioplastic container prototypes except the one made of PHA P1008, which biodegraded an average of $16.4 \%$ across the two trial sites. The two fiber containers biodegraded at a similar rate to the PHA Pl008 container in Iowa, but degraded at a much faster rate in Nevada during the phase- 2 trial. The absence of container effect on plant quality for the nursery trial is likely due to two main factors: 1) the larger amount of medium in the containers that dilutes any potential effect from the container 
material and 2) the inert character of the durable materials chosen for evaluation in the nursery trial.

The results of the long-term biodegradation trial provide perhaps the best indications of overall biodegradability in soil of bioplastic and biocomposite materials for horticulture containers. Because of the time required to complete such a trial, only results with phase-1 materials are presented in this report. Most of the materials evaluated in the long-term trial continued to biodegrade consistently with the results shown in the 24-week trial (Table 3), but the rate of degradation of two of the prototypes, PLA-Soy SP.A and PLA-Soy SP, slowed considerably after 6 months in soil and showed either no increase in degradation percentage from 6 months to $\mathbf{1 . 5}$ years or only a small increase, respectively (Table 5 ). This phenomenon has been ascribed to the early loss of the soy component of the blend, which is highly biodegradable, and the continued persistence of the PLA component, which has a very low rate of biodegradation (Yang et al., 2015). For the remainder of the materials in the trial, only those with very low rates of biodegradation showed no difference in degradation percentage for units assessed at $\mathbf{1 . 5}$ years compared with those assessed at 6 months (Table 5). The other general conclusion provided by results of our long-term trial is that biodegradation in a temperate climate, such as that in Iowa, slows considerably during the winter months, a conclusion supported by the absence of degradation for any of the materials during the period between 6 months and 1 year, a timespan that ran through winter from 29 Nov. 2012 to 17 May 2013.

Of the prototype materials evaluated in the long-term trial, the PHAbased composites showed the greatest rates of biodegradation. Specifically, samples of PHA P4010, PHA P1004DDGS, and PHA P1003-DDGS biodegraded more than $78 \%$ in 1.5 years (Table 5). The improvement in biodegradability provided by the inclusion of DDGS in the PHA-based materials is even more apparent after 1.5 years than it was after 24 weeks in soil. The compounding of $10 \%$ DDGS with PHA P1004 and PHA P1003 increased biodegradation of these PHA-based materials from $18 \%$ to

Table 5. Long-term biodegradation in soil of plant container samples made from phase-1 bioplastics and biocomposites or commercially available container materials and buried in soil in Iowa for 6 mo., 1 year, and 1.5 years. Percentage degradation of materials was calculated as the percentage weight loss of material samples during their duration in soil. Percentage degradation of materials in each trial plot was calculated as the percentage weight loss of material samples during their treatment duration in soil.

\begin{tabular}{|c|c|c|c|}
\hline \multirow[b]{2}{*}{ Container material $^{\mathrm{z}}$} & \multicolumn{3}{|c|}{ Degradation in soil (\%) } \\
\hline & $6 \mathrm{mo.}$ & $1 \mathrm{yr}$ & 1.5 years \\
\hline \multicolumn{4}{|l|}{ PLA-based blends or composites } \\
\hline PLA-soy SP.A $(50 / 50)$ & $52.6 \mathrm{a} \mathrm{A}^{\mathrm{y}}$ & $49.3 \mathrm{ab} A$ & $54.0 \mathrm{~d}-\mathrm{f} \mathrm{A}$ \\
\hline PLA-soy SP $(50 / 50)$ & 50.2 a B & $49.6 \mathrm{ab} \mathrm{B}$ & $53.5 \mathrm{~d}-\mathrm{f} \mathrm{A}$ \\
\hline PLA-DDGS $(90 / 10)$ & $15.5 \mathrm{~h}-\mathrm{j} B$ & $15.0 \mathrm{f}-\mathrm{i} \mathrm{B}$ & 19.6 i A \\
\hline PLA-corn stover $(90 / 10)$ & $13.6 \mathrm{ij} \mathrm{B}$ & $13.3 \mathrm{~g}-\mathrm{j} B$ & $15.6 \mathrm{i} \mathrm{A}$ \\
\hline PLA-nanoclay $(90 / 10)$ & $0.2 \mathrm{k} \mathrm{A}$ & $0.3 \mathrm{j} \mathrm{A}$ & $0.4 \mathrm{j} \mathrm{A}$ \\
\hline PLA $(100 \%)$ & $0.2 \mathrm{k} \mathrm{A}$ & $0.2 \mathrm{j} \mathrm{A}$ & $0.2 \mathrm{j} \mathrm{A}$ \\
\hline \multicolumn{4}{|l|}{ PHA-based blends or composites } \\
\hline PHA P4010 (30\% starch) & 52.1 a C & $61.2 \mathrm{a} \mathrm{B}$ & $93.2 \mathrm{ab} \mathrm{A}$ \\
\hline PHA P1008 (10\% starch) & $16.7 \mathrm{~g}-\mathrm{i} \mathrm{B}$ & $19.2 \mathrm{e}-\mathrm{i} \mathrm{B}$ & $44.4 \mathrm{f}-\mathrm{h} \mathrm{A}$ \\
\hline PHA P1004-DDGS $(90 / 10)$ & $42.5 \mathrm{ab} \mathrm{B}$ & $46.8 \mathrm{a}-\mathrm{c} B$ & 81.9 c A \\
\hline PHA P1003-DDGS $(90 / 10)$ & $36.3 \mathrm{~b}-\mathrm{d} \mathrm{C}$ & $43.4 \mathrm{~b}-\mathrm{d} \mathrm{B}$ & 78.9 c A \\
\hline PHA P1004 & $8.1 \mathrm{i}-\mathrm{k} \mathrm{B}$ & $9.2 \mathrm{i}-\mathrm{j} \mathrm{B}$ & $18.0 \mathrm{i} \mathrm{A}$ \\
\hline PHA P1003 & $5.4 \mathrm{jk} \mathrm{B}$ & $5.6 \mathrm{j} \mathrm{B}$ & $11.9 \mathrm{i} \mathrm{A}$ \\
\hline \multicolumn{4}{|l|}{ Commercial biocontainers } \\
\hline Wood fiber & $46.2 \mathrm{ab} \mathrm{B}$ & $46.2 \mathrm{a}-\mathrm{c} B$ & 100 a A \\
\hline Paper fiber & $45.0 \mathrm{ab} \mathrm{B}$ & $46.8 \mathrm{a}-\mathrm{c} A B$ & $60.0 \mathrm{de} \mathrm{A}$ \\
\hline Peat fiber & 30.8 c-e B & $30.2 \mathrm{~d}-\mathrm{f} \mathrm{B}$ & $80.3 \mathrm{c} \mathrm{A}$ \\
\hline Coir fiber & $31.1 \mathrm{c}-\mathrm{e} \mathrm{B}$ & 33.9 c-e B & 80.9 с A \\
\hline TerraShell $^{\mathrm{x}}$ & $8.1 \mathrm{i}-\mathrm{k}$ B & $9.8 \mathrm{~h}-\mathrm{j} \mathrm{AB}$ & $15.1 \mathrm{i} \mathrm{A}$ \\
\hline Petroleum control (PP) & $0.0 \mathrm{k} \mathrm{A}$ & $0.0 \mathrm{jA}$ & $0.0 \mathrm{j} \mathrm{A}$ \\
\hline
\end{tabular}

${ }^{\mathrm{z} S p e c i f i c ~ b l e n d ~ r a t i o s ~ o f ~ b i o p l a s t i c ~ a n d ~ b i o c o m p o s i t e ~ m a t e r i a l s ~ f o r ~ i n j e c t i o n-m o l d e d ~ p r o t o t y p e s ~ a r e ~ o n ~ a ~ p e r-w e i g h t ~}$ basis; PLA = polylactic acid, SP = soy polymer, SP.A = soy polymer with adipic anhydride, DDGS = dried distillers grains with solubles, $\mathrm{PHA}=$ polyhydroxyalkanoate, $\mathrm{PHA}$ P4010 = PHA blend with $30 \%$ starch, $\mathrm{PHA}$ P1008 = PHA blend with $10 \%$ starch, PHA P1003 and P1004 are pure PHA formulations, PP = polypropylene.

${ }^{y}$ Means within a column followed by the same lowercase letter are not different according to Tukey-Kramer honest significant difference (HSD) at $P \leq 0.05(\mathrm{n}=3)$. Means within a row followed by the same uppercase letter are not different according to Tukey-Kramer HSD at $P \leq 0.05(\mathrm{n}=3)$.

${ }^{x}$ Summit Plastic Co., Akron, OH.

$81.9 \%$ and from $11.9 \%$ to $78.9 \%$ in the 1.5 year trial, respectively. These observations are consistent with work by Madbouly et al. (2014) that demonstrated about six times greater biodegradation of PHA composites in soil after 24 weeks when samples were formulated with 10\% DDGS and showed that partial substitution of DDGS for PHA could significantly lower material cost with little to no reduction in material performance (Madbouly et al., 2014). The improvement in biodegradation gained by compounding DDGS or corn stover with PLA was less substantial, but still increased degradation from $0.2 \%$ to $19.6 \%$ and $15.6 \%$ over the 1.5 -year trial, respectively. All four of the commercially available fiber containers degraded very well during the 1.5 years in soil, but the commercially available TerraShell container degraded only $15.1 \%$.
Our tests for potential phytotoxic properties of materials before and after degradation in soil were conducted according to the standardized guidelines for terrestrial plant testing of seedling emergence and seedling growth defined by Organisation for Economic Co-operation and Development (2006) and were performed by using tomato 'Rutgers' as the test species. Although the standard maximum level required for testing the toxicity of a chemical is defined in the guidelines to be 1000 $\mathrm{mg} \cdot \mathrm{kg}^{-1}$, we tested all materials in our trials at both this level and at 10 times this level $\left(10,000 \mathrm{mg} \cdot \mathrm{kg}^{-1}\right)$ to insure any potential toxic reaction could be detected. Results with all materials evaluated in both phase- 1 and phase- 2 trials, and with each material both before and after 24 weeks of degradation in soil, showed no reduction in seed germination and no evidence of 
stunted growth, chlorosis, discoloration, mortality, or abnormal morphology for test plants at either the $1000 \mathrm{mg} \cdot \mathrm{kg}^{-1}$ treatment or the $10,000 \mathrm{mg} \cdot \mathrm{kg}^{-1}$ treatment. Therefore, we conclude that all of the materials evaluated in our trials should be considered nontoxic for use as horticulture containers and for end-of-life decomposition in soil after use.

On the basis of results of these evaluations, we conclude that biodegradation in soil should be an effective end-of-life option for biobased containers made of PHA-based blends and composites that contain degradable, biobased fibrous fillers such as DDGS or corn stover and for PHA blended with a degradable copolymer such as Soy SP.A. We suggest that PLA-based blends and composites with these types of fillers and copolymers might also be considered for this end-of-life option, but it is likely that PLA-based container materials will leave a residue of low-density PLA material that may persist for many years. The impact of annual incorporation of such containers in landscape or garden soils and potential accumulation of this low-density PLA residue is a topic that requires further study. Because PLA is $100 \%$ biorenewable, biocompatible, and nontoxic, it is possible that the effects of low-density PLA residue in soil could provide a function similar to that of naturally derived lignin and other forms of natural organic matter. The use of PLA blended with soy polymer is an especially attractive option because soy is a plant-based biorenewable material, and containers made from this blend provide an added benefit over petroleum-based containers and other types of bioplastics by providing a nitrogen-fertilizing effect for plants growing in them (Grewell et al., 2014; Schrader et al., 2013). We confirm that commercially available fiber containers biodegrade readily and are suitable for end-of-life degradation in soils under common landscape and garden conditions. The biodegradation rate of the commercially available TerraShell material is low compared with many of our prototype materials, and although it is considered degradable and compostable in accordance with EN 13432 European standards for packaging recoverable through composting and biodegradation (Association Française de Normalisation, 2000) and NF U52-001 French standards of biodegradable materials for use in agriculture and horticulture (Association Française de Normalisation, 2005), our results indicate that its rate of biodegradation is likely not suitable for end-of-life decomposition in landscape or garden soils.

Along with detailed results that quantify the performance and biodegradation of each container material, our results also illustrate the complexity of developing optimal containers that can fulfill the functional advantages of petroleum-based plastics, yet biodegrade readily in soil after use. Finding a biobased material that can function as well as petroleum plastic will not be difficult, but finding one that will also biodegrade quickly in soil and is affordable will be more challenging. Generally, containers made of biobased materials that are durable and hold up well during crop production degrade more slowly in soil than those that are less durable during crop production. This phenomenon is not surprising since many of the same physical and microbial forces are at work during both stages of a container's life cycle. On the basis of this trend, we might conclude that containers that biodegrade relatively quickly in soil would only be suitable for short-cycle crops, and biocontainers intended for use with longcycle crops, such as nursery species, would need to be made of biobased materials that are either nonbiodegradable or degrade very slowly. Although this generalization seems to hold true for most of the materials we tested, PHA-based composites may be exceptions to this trend.

In greenhouse evaluations with 4.5-inch prototypes, containers made of PHA-DDGS $(80 / 20)$ received high scores for container rating in both 6- and 16-week crop cycles, yet biodegraded in soil at a relatively high rate $(48.5 \%$ and $43.5 \%$ in Iowa and Nevada soils in 24 weeks, respectively; Table 4). In evaluations of \# 1 trade gallon prototypes, containers made of PHA P1008 (10\% starch) received the highest score possible for container rating, yet still degraded an average of $16.4 \%$ during 24 weeks in soil (Table 4 ) and $44.4 \%$ in soil over 1.5 years (Table 5). Although these characteristics of PHA-based composites demonstrate that they could be superior biobased alternatives to petroleum-based plastics, they do have drawbacks. With only a few exceptions, the plant quality of crops produced in PHA-based containers were lower than plants produced in any and all PLA-based containers we evaluated (Tables 3 and 4 ). We suspect that the reduced growth and health of plants grown in PHA-based containers may be related to sequestration of nitrogen $(\mathrm{N})$ by microbes to enable metabolism of available carbon from the PHA material, making some of the $\mathrm{N}$ unavailable for uptake by the plant (Fischer et al., 2010; Kuzyakov and $\mathrm{Xu}, 2013$ ). Regardless of the cause, we have found that culture of plants in 4.5-inch containers made of PHA materials requires a higher rate of fertilizer application to produce a plant of equal quality to those produced in PLA-based containers or control containers. This drawback of PHA-based containers was not apparent in nursery trials with \#l trade gallon prototypes (Table 4). Two other drawbacks of PHA materials now are their high cost (nearly twice the cost of PLA) and limited availability (about six times less produced than PLA), but these issues will likely fade as production of PHA increases through the next decade (European Bioplastics, 2013; Voegele, 2012).

Depending on the amount and type of copolymer or filler used, PLAbased materials can function on a scale from extremely durable and nondegradable to marginally durable and highly biodegradable. The most interesting PLA-based prototype containers developed so far are those made of blended PLA-Soy, a binary material that is sufficiently durable for crop cycles from 6 to 16 weeks (Table $4)$, can provide up to $80 \%$ of the synthetic fertilizer required for production of high-quality short-cycle crops (Yang et al., 2015), and can biodegrade $54 \%$ in soil in 1.5 years (Table 5). Both PLA and Soy polymer materials cost less than most biopolymers, are readily available now, and will continue to increase in availability in the future (Yang et al., 2015). The potential for development of superior, sustainable, reasonably priced PLA-based horticulture containers for applications from short-cycle greenhouse crops to long-cycle nursery crops is very promising, but results 
suggest that biodegradability of these materials will likely be inversely proportional to durability.

The adoption of biorenewable plastics and composites as replacements for petroleum-based plastics in single-use horticulture containers could provide a substantial improvement in sustainability for the container-crops industry (Yang et al., 2015). Determination of the best materials for biobased containers will require the consideration of numerous factors, including performance, durability, biodegradability, overall environmental impact, crop quality, ease of implementation, availability, and cost. Our results provide practical data that quantify performance, crop quality, and biodegradation, and indicate strong potential for development of high-performing biobased containers that can perform as well as or better than petroleum-based containers with much lower environmental impact.

\section{Literature cited}

Association Française de Normalisation. 2000. Packaging: Requirements for packaging recoverable through composting and biodegradation: Test scheme and evaluation criteria for the final acceptance of packaging. AFNOR Publ. NF EN 13432 .

Association Française de Normalisation. 2005. Biodegradable materials for use in agriculture and horticulture: Mulching products: Requirements and test methods. AFNOR Publ. NF U52-001.

Behe, B.K., B.L. Campbell, C.R. Hall, H. Khachatryan, J.H. Dennis, and C. Yue. 2013. Consumer preferences for local and sustainable plant production characteristics. HortScience 48:200-208.

Bronick, C.J. and R. Lal. 2005. Soil structure and management: A review. Geoderma 124:3-22.

Chappell, M. and G.W. Knox. 2012. Alternatives to petroleum-based containers for the nursery industry. Univ. Georgia Coop. Ext. Bul. 1407.

Currey, C., J. Schrader, K. McCabe, W. Graves, D. Grewell, G. Srinivasan, and S. Madbouly. 2014. Bioplastics for greenhouses: Soy what? GrowerTalks 77(9):70-74.

European Bioplastics. 2013. Institute for Bioplastics and Biocomposites: Market. 6 Nov. 2014. <http://en.european-bioplastics. org/market>.

Evans, M.R. and D. Karcher. 2004. Properties of plastic, peat, and processed poultry feather growing containers. HortScience 39:1008-1011.

Fischer, H., J. Ingwersen, and Y. Kuzyakov. 2010. Microbial uptake of low-molecularweight organic substances out-competes sorption in soil. Eur. J. Soil Sci. 61:504 513.

Gómez, E.F. and F.C. Michel, Jr. 2013. Biodegradability of conventional and biobased plastics and natural fiber composites during composting, anaerobic digestion, and long-term soil incubation. Polym. Degrad. Stabil. 98:2583-2591.

Grewell, D., G. Srinivasan, J. Schrader, W. Graves, and M. Kessler. 2014. Sustainable materials for horticultural application. Plastics Eng. 70(3):44-52.

Hall, C.R., B.L. Campbell, B.K. Behe, C. Yue, R.G. Lopez, and J.H. Dennis. 2010. The appeal of biodegradable packaging to floral consumers. HortScience 45:583-591.

Koeser, A., S.T. Lovell, M. Evans, and J.R. Stewart. 2013. Biocontainer water use in short-term greenhouse crop production. HortTechnology 23:215-219.

Kuehny, J.S., M. Taylor, and M.R. Evans. 2011. Greenhouse and landscape performance of bedding plants in biocontainers. HortTechnology 21:155-161.

Kuzyakov, Y. and X. Xu. 2013. Competition between roots and microorganisms for nitrogen: Mechanisms and ecological relevance. New Phytol. 198:656-669.

Li, C., J. Moore-Kucera, C. Miles, K. Leonas, J. Lee, A. Corbin, and D. Inglis. 2014. Degradation of potentially biodegradable plastic mulch films at three diverse U.S. locations. Agroecology Sustainable Food Systems 38:861-889.

Lu, H., S.A. Madbouly, J.A. Schrader, M.R. Kessler, D. Grewell, and W.R. Graves. 2014. Novel bio-based composites of polyhydroxyalkanoate (PHA)/distillers dried grains with solubles (DDGS). RSC Adv. 4:39802-39808.
Madbouly, S.A., J.A. Schrader, G. Srinivasan, K. Lui, K.G. McCabe, D. Grewell, W.R. Graves, and M.R. Kessler. 2014. Biodegradation behavior of bacterial-based polyhydroxyalkanoate (PHA) and DDGS composites. Green Chem. 16:1911-1920.

Martínez, Á.T., M. Speranza, F.J. RuizDueñas, P. Ferreira, S. Camarero, F. Guillén, M.J. Martínez, A. Gutiérrez, and J.C. del Río. 2005. Biodegradation of lignocellulosics: Microbial, chemical, and enzymatic aspects of the fungal attack of lignin. Int. Microbiol. 8:195-204.

McCabe, K.G., J.A. Schrader, S. Madbouly, D. Grewell, and W.R. Graves. 2014. Evaluation of biopolymer-coated fiber containers for container-grown plants. HortTechnology 24:439-448.

Organisation for Economic Co-operation and Development. 2006. OECD guidelines for the testing of chemicals. Test No. 208: Terrestrial plant test: Seedling emergence and seedling growth test. OECD, Paris, France. doi: 10.1787/9789264070066-en.

Pyle, D. 1999. Data preparation for data mining. Morgan Kaufmann Publishers, San Francisco, CA.

Schrader, J.A. 2013. Report on the annual consumption of plastics for specialty-crop containers in the United States. 12 Dec. 2013 . <http:// www.public.iastate.edu/ bioplastic/ Supplementary/AnnualPlastic.html>.

Schrader, J.A., G. Srinivasan, D. Grewell, K.G. McCabe, and W.R. Graves. 2013. Fertilizer effects of soy-plastic containers during crop production and transplant establishment. HortScience 48:724-731.

Srinivasan, G. 2014. Processing: Biobased polymers and composites for container production. 6 Nov. 2014. <http://hvp. osu.edu/bioplastics/?p $=234>$.

Voegele, E. 2012. European Bioplastics releases 2016 market forecast. 16 Oct. 2012. <http://biomassmagazine.com/ articles $/ 8183$ /european-bioplasticsreleases-2016-market-forecast $>$.

Yang, S., S.A. Madbouly, J.A. Schrader, G. Srinivasan, D. Grewell, K.G. McCabe, M.R. Kessler, and W.R. Graves. 2015. Characterization and biodegradation behavior of bio-based poly(lactic acid) and soy protein blends for sustainable horticultural applications. Green Chem. 17:380-393. 